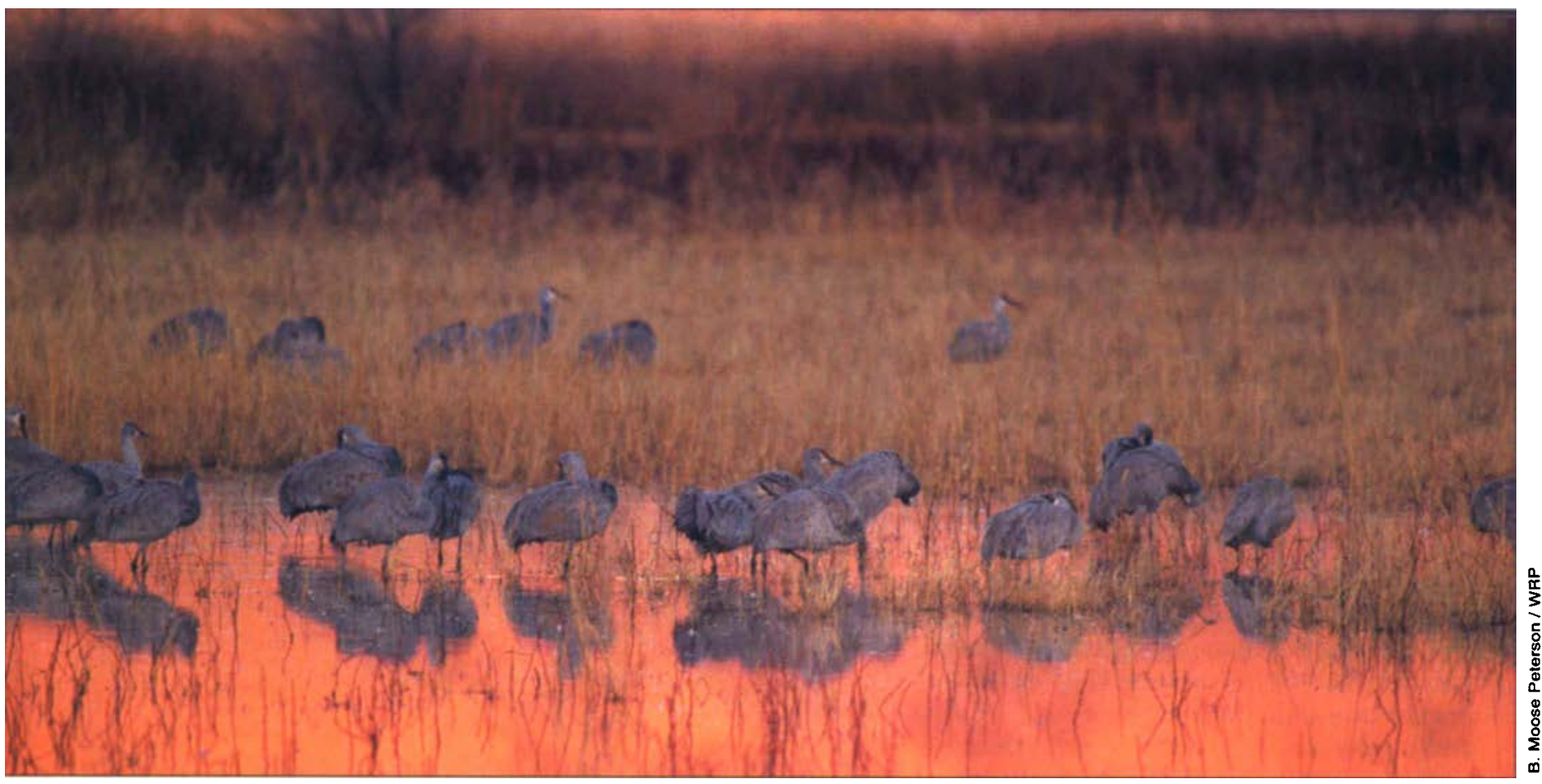

\title{
Late season hay harvest provides habitat for marshland birds
}

\author{
Wade L. Epperson $\square$ John M. Eadie $\quad \square \quad$ Daniel B. Marcum $\quad$ E. Lee Fitzhugh $\quad \square \quad$ Richard E. Delmas
}

Haying of alkaline marsh and nonnative annual grasses on the Ash Creek Wildlife Area has been a standard practice to enhance bird habitat since 1986. Harvest begins each year after Aug. 15 to minimize disturbance to nests and broods of greater sandhill cranes (Grus canadensis tabida) and other marsh-nesting birds. Field studies in 1996 revealed that the abundance and diversity of birds on hayed plots was equal to or greater than the abundance and diversity of birds on nonhayed plots. Greater sandhill cranes were also more abundant and spent more time foraging and less time being vigilant on hayed plots relative to plots that had not been hayed. Harvest of wild hay after nesting and brood-rearing can therefore be an important management tool to create a mosaic of habitats required by many species of marshland birds.
The Ash Creek Wildlife Area (ACWA) dominates the Big Valley area of Lassen and Modoc counties. For more than a century, the area was operated as a cattle ranch and subjected to haying, grazing and burning over various periods. In the early 1980 s, the area was recognized as critical wildlife habitat, especially for migratory waterfowl and greater sandhill cranes. In 1986, more than 14,000 acres were purchased by the state of California to be managed by the California Department of Fish and Game (CDFG), in part, to provide habitat for threatened, endangered and sensitive species. The ACWA is one of the few places in the state where greater sandhill cranes a sensitive species in California - reproduce successfully, supporting up to 50 breeding pairs. An additional 6,000 to 8,000 greater and lesser sandhill cranes utilize the ACWA as a staging area on their spring migration north from the Central Valley of California to breeding grounds in Oregon, Washington and British Columbia.
The influence of agriculture upon wildlife is an important issue. On the ACWA, haying is used as a management tool to improve habitat quality for greater sandhill cranes (Grus canadensis tabida) and other birds. Up to 1,000 acres of wild hay on the ACWA have been harvested annually since 1986. Although the intent of haying is to provide foraging habitat for cranes, some concerns have been raised that crane chicks (colts) may be killed or injured by haying equipment, or that colts may be driven from their territories and attacked by other territorial adults. To mitigate these concerns, the CDFG has prohibited haying before Aug. 15, the date by which colts should have fledged (i.e., are capable of flight) and when neither haying equipment nor aggressive attacks by adult cranes are likely to pose any threat to young cranes. Nevertheless, strong community interest exists in monitoring the effects of haying to evaluate and validate this management practice. This study examines the 
impact of late-summer haying on bird populations on the ACWA.

\section{Harvest of wild hay}

The Ash Creek Wildlife Area is dominated by upland sagebrush steppe and related wetland types associated with the Great Basin. Areas that are hayed comprise alkaline marsh/ meadow and non-native annuals (fig. 1). Hay is harvested and removed by local farmers for their personal use. Since 1986, hayed areas varied in size and shape because of different custom harvesters, rough terrain and wet spots. Potential hayed sites are designated for wildlife purposes and comprise less than $10 \%$ of the total area. These areas are interspersed with a series of canals and tributaries feeding into the swamp (fig. 1). The vegetation adjacent to these waterways is left standing, creating pockets of undisturbed dense vegetation throughout the hayed areas.

In 1996, we collected vegetation samples in July (prior to harvest) and August (after harvest) to quantify the effect of haying on the height and biomass of wild hay. As expected, haying significantly reduced vegetation height and vegetation biomass (table 1). Small but significant differences existed between hayed and nonhayed plots in July, prior to the current year's harvest. However, the greatest differences occurred after harvest in August. On nonhayed plots, vegetation stands characteristically became dense with considerable residual dry matter (litter). On hayed plots, litter was reduced and the vegetation was shorter and less dense.

\section{Surveying birds on plots}

To examine the effect of the hay harvest on bird populations, we established eight study plots, 200 yards radius, in comparable areas of alkali marsh and alkali meadow plant communities (fig. 1). Four study plots (A, B, C and D) were located in nonhayed areas, three plots (F, G and $H$ ) were placed in areas that were hayed in late season (August) and one plot (E) was established on private property adjacent to the ACWA and was hayed in June.

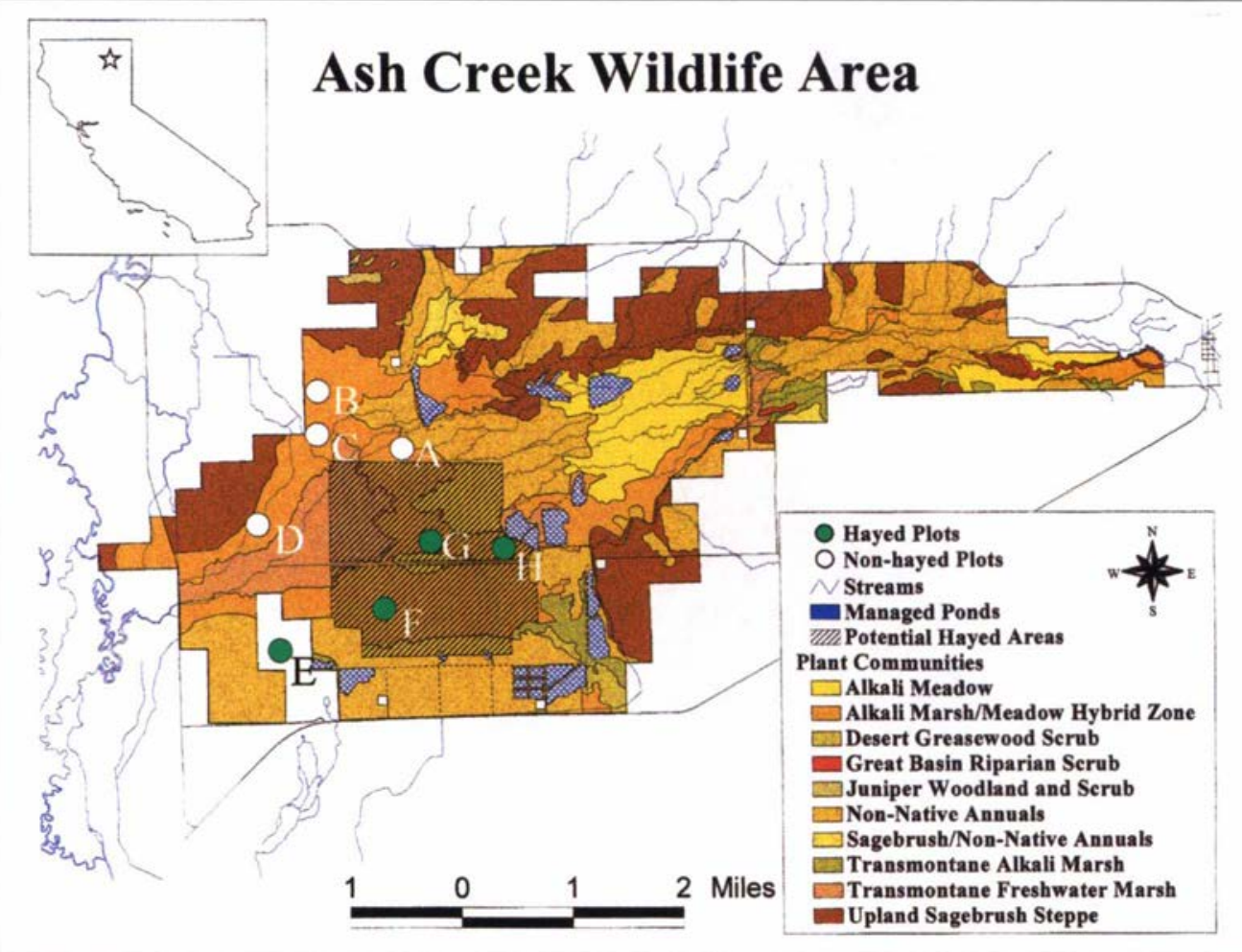

Fig. 1. Location map for Ash Creek Wildlife Area, Bieber. Plots A, B, C and D are nonhayed plots, plot $E$ was hayed early, and plots $F, G$ and $H$ were hayed late in 1996.

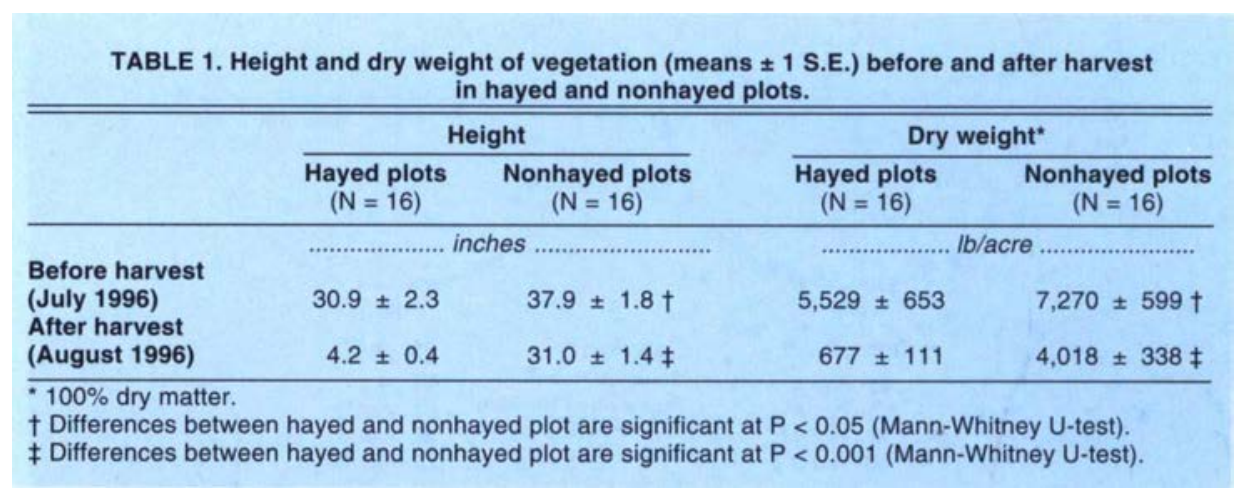

We began observing birds on June 24, 1996, when the marsh became dry enough to allow vehicle access.

Haying began on Aug. 19 and observations continued through Aug. 29, 1996. Observations were made from a pickup-mounted platform at a height of 9 feet above the ground. All birds of duck-size or smaller were counted to a distance of 50 yards. Sandhill cranes and other large birds were counted to 200 yards. Raptors were recorded if they broke the vertical plane of the 200-yard plot boundary. With the exception of raptors, our efforts focused on birds that landed or fed within the plot radius. Accordingly, we did not census species such as tree swallows
(Tachycineta bicolor) that were only observed flying through or over the plots.

All plots were censused twice weekly. Half of each circular plot was observed every 5 minutes, and observation periods for each plot lasted 40 minutes (20 minutes per side). To reduce sampling bias associated with time-of-day effects, we observed half of the plots in the morning and the other half in the afternoon. This order was then reversed in the next set of observations and the sequence in which plots were visited was systematically rotated. Morning observation periods began one-half hour before sunrise; afternoon sample periods 
were scheduled to end one-half hour after sunset. The only exception to this schedule was plot $B$, which was always visited before plot $C$; the only access to plot $C$ was through plot $B$.

\section{Effects of previous haying}

We compared the dispersion, density and diversity of bird species on
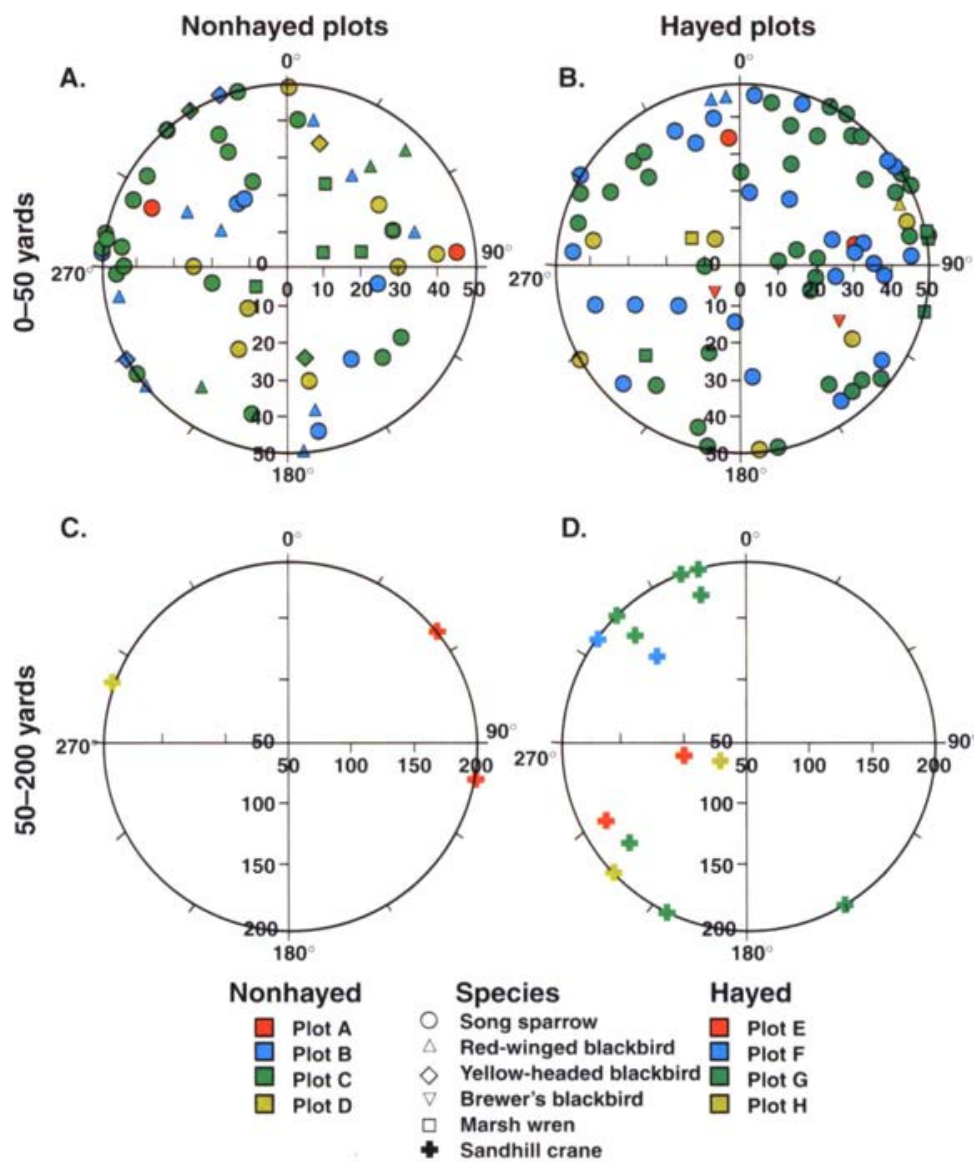

Fig. 2. Distribution of bird species on hayed and nonhayed plots. A. nonhayed 0-50 yards; $B$. hayed $0-50$ yards; C. nonhayed $50-200$ yards; $D$. hayed $50-200$ yards.

\begin{tabular}{|c|c|c|}
\hline \multirow[b]{2}{*}{ Species } & \multicolumn{2}{|c|}{ No. of individuals* } \\
\hline & $\begin{array}{c}\text { Hayed } \\
(\mathrm{N}=90)\end{array}$ & $\begin{array}{l}\text { Nonhayed } \\
(\mathrm{N}=120)\end{array}$ \\
\hline Greater sandhill crane (Grus canadensis) & $0.153 \pm 0.049$ & $0.037 \pm 0.024 \dagger$ \\
\hline Northern harrier (Circus cyaneus) & $0.119 \pm 0.019$ & $0.096 \pm 0.017$ \\
\hline Short-eared owl (Asio flammeus) & $0.011 \pm 0.005$ & $0.021 \pm 0.009$ \\
\hline Song sparrow (Melospiza melodia) & $0.389 \pm 0.066$ & $0.235 \pm 0.045 \dagger$ \\
\hline Red-winged blackbird (Agelaius phoeniceus) & $0.036 \pm 0.013$ & $0.052 \pm 0.018$ \\
\hline $\begin{array}{l}\text { Yellow-headed blackbird } \\
\text { (Xanthocephalus xanthocephalus) }\end{array}$ & $0 \pm 0$ & $0.013 \pm 0.006$ \\
\hline Brewer's blackbird (Euphagus cyanocephalus) & $0.003 \pm 0.003$ & $0 \pm 0$ \\
\hline Marsh wren (Cistothorus palustris) & $0.014 \pm 0.007$ & $0.037 \pm 0.019$ \\
\hline Total number of individuals & $0.725 \pm 0.083$ & $0.492 \pm 0.057 \dagger$ \\
\hline Total number of species & $0.283 \pm 0.026$ & $0.208 \pm 0.019 \dagger$ \\
\hline
\end{tabular}

birds on hayed plots was equal to or higher than that on nonhayed plots (table 2). When all censuses from hayed plots were pooled and compared to those from nonhayed plots, we found that the total number of individuals, the number of species, the number of sandhill cranes and the number of song sparrows were significantly higher on hayed plots (table 2). Haying did not significantly reduce the abundance of any species.

Brewer's blackbirds probably replaced yellow-headed blackbirds on the hayed plots, although the average abundance of both species was low (table 2).

These analyses ignore variation among plots and pool data from sev-
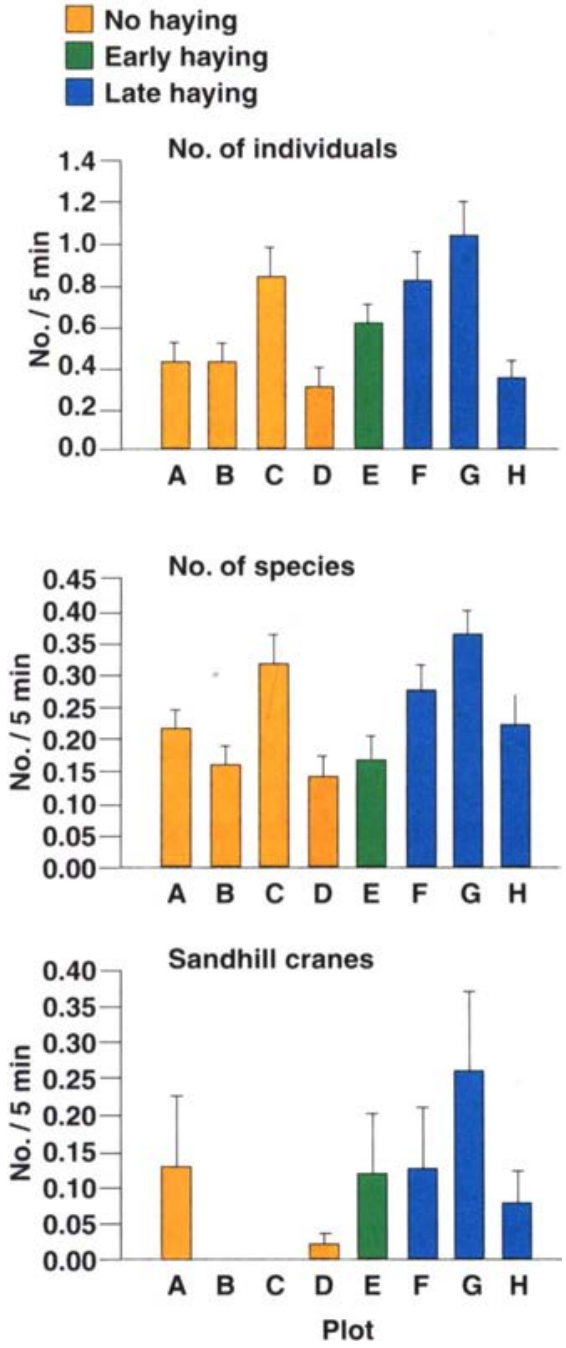

Fig. 3. Average number of individual birds ( 1 S.E.), number of bird species and number of sandhill cranes observed on each study plot prior to current-year hay harvest. 
eral different dates. Accordingly, we reanalyzed the data to compare each plot separately (fig. 3). On the basis of this analysis, we found significant differences among plots in the abundance and diversity of bird species and in the abundance of sandhill cranes. Plots that had been hayed late in the previous year $(F, G$ and $H$ ) had more individuals and more species of birds than three of the four nonhayed plots (A, B and $D)$. The one site that was hayed early (E) was comparable to the nonhayed plots (we did not test for a statistical difference for this plot given the limited sample size $(\mathrm{N}=1)$; comparison of early-season haying to lateseason haying could be a useful direction for future study). Sandhill cranes occurred regularly on all four of the hayed plots, but were observed frequently on only one nonhayed plot (fig. 3).

\section{Immediate effects of haying}

To measure changes in habitat use by resident birds and isolate the immediate effects of haying, we next analyzed the 4-week time period bracketing the first day of haying (i.e., 2 weeks before harvest and two weeks after harvest). By late summer, habitat use for many birds changed on the wildlife area as water receded in the marsh and vegetation dried. Because some bird species observed earlier in the year were uncommon or not observed later in the year (e.g., yellow-headed blackbirds, red-winged blackbirds), we restricted the analysis to the immediate period before and after harvest.

We compared the number of birds on hayed plots before harvest to the number observed on the same plots after harvest. There was no significant decrease in bird densities or species diversity on hayed plots following harvest (fig. 4). In contrast, both densities and diversity tended to be higher after harvest, although the differences were not statistically significant.

\section{Benefits to cranes}

The census data indicate that sandhill cranes occurred more frequently on hayed plots than on nonhayed plots (table 2, fig. 3). We also examined the time budgets of cranes to as-

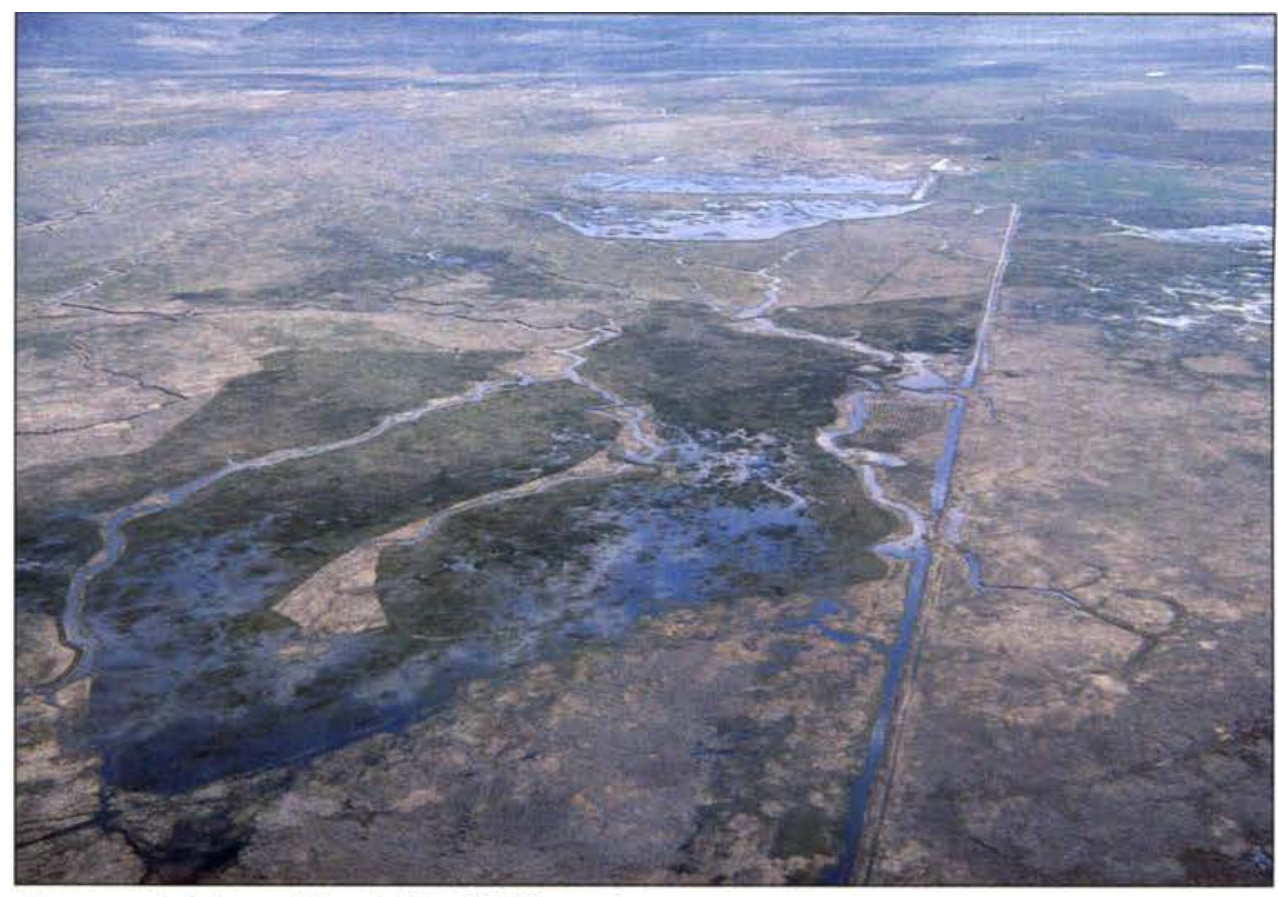

Above, aerial view of flooded hayfield in spring.

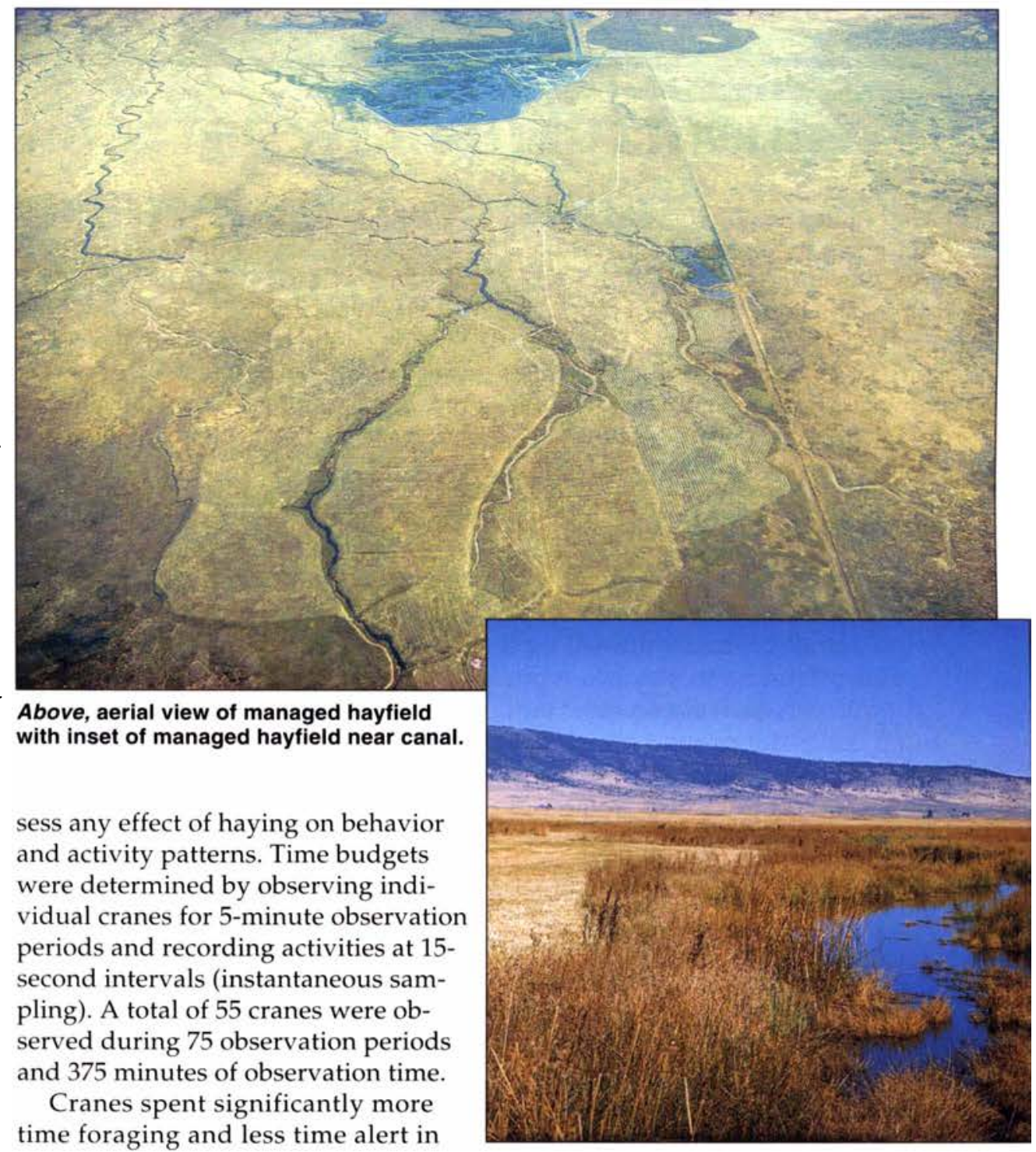




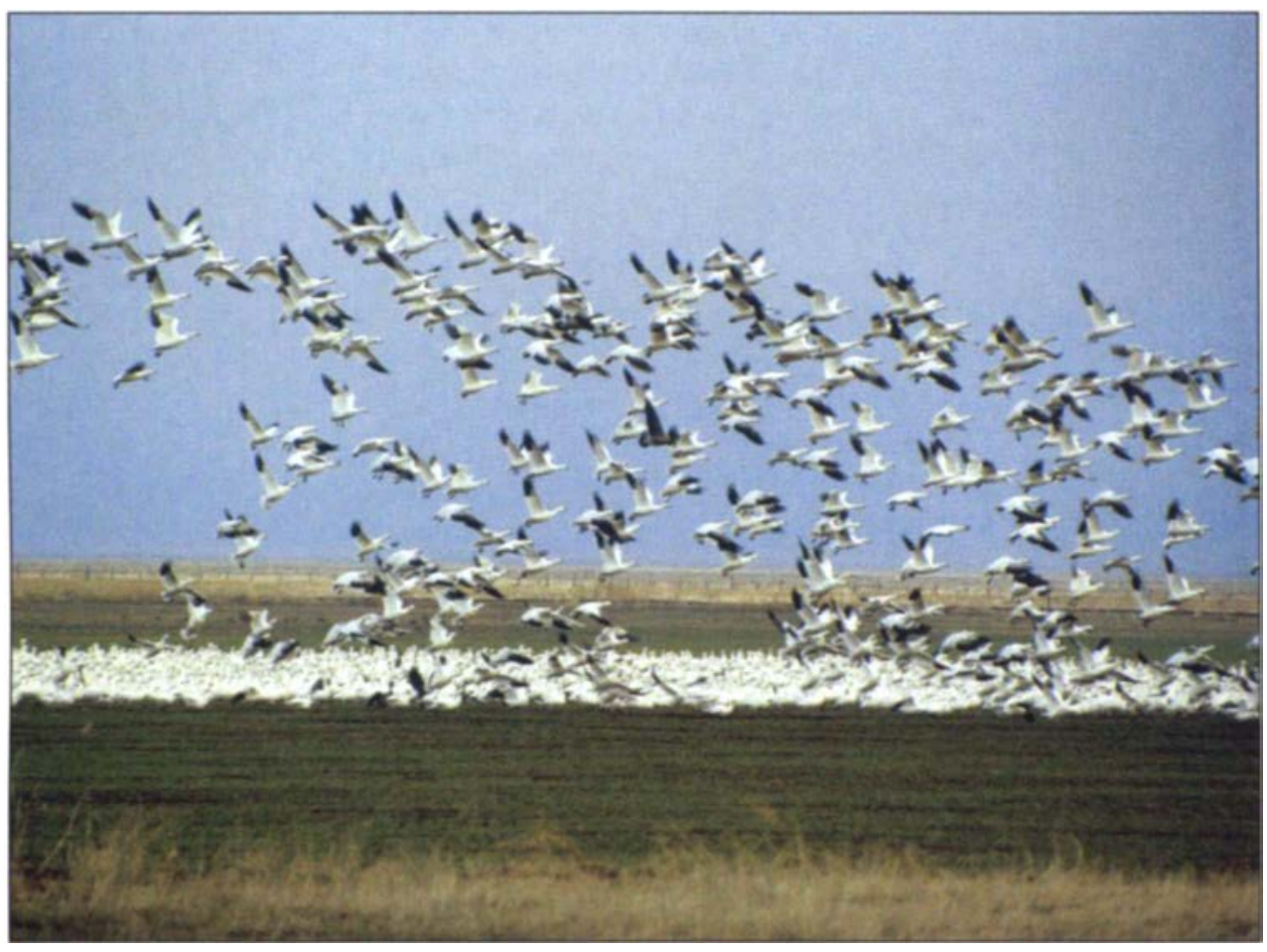

Haying promotes earlier spring forage for migrating waterfowl such as geese.

hayed plots (fig. 5). There were no differences in any other activity patterns. Our interpretation of these results is that, in the hayed plots, vegetation is less dense so travel, foraging and vigilance by cranes would be more efficient. An increased ability to detect approaching predators would result in less time required for vigilance and more time available for foraging. Reduced litter and vegetation cover in hayed areas would also enhance the ability of cranes to find and capture prey.

\section{Using haying to enhance habitat}

Typically, haying in Big Valley begins in June and July, a time when birds may be nesting in hay fields. Haying on the ACWA is unique because it occurs in August. Late summer hay has little commercial value, but it can be a valuable wildlife management tool. During spring migration, cranes and waterfowl depend on green plant shoots and invertebrates to provide important nutrient and energy reserves for migration and subsequent reproduction. Haying removes excess plant litter that would otherwise block sunlight. These areas absorb more solar radiation, warming soils earlier and promoting earlier spring plant growth than areas that are covered with dense litter. Rapid meadow regrowth provides succulent, nutritious forage for migrating waterfowl, and the shortened vegetation provides improved visibility of food items while reducing the risk of predation to foraging birds.

Some concerns have been voiced that haying is inappropriate on a stateowned wildlife area, presumably because it is thought that such activities disrupt wildlife and destroy wildlife habitat. Our results indicate that haying does not lead to a reduction in bird densities, either immediately after haying, or in the following year. For some species, such as sandhill cranes, haying appears to be beneficial in providing critical foraging habitat. On the basis of our results from 1996, we conclude that late-season harvest of native hay has few detrimental effects on local avian populations.

Our study did not consider the effect of haying on activities of colts (crane chicks), nest densities of cranes or other birds, or spring staging activities of migratory waterfowl. These are important areas that we intend to address in future studies. We also caution that management activities such as haying should be accompanied by careful monitoring to ensure that wildlife management goals and objectives are achieved. With these caveats in mind, we believe that late-season harvest of wild hay can be a valuable tool to
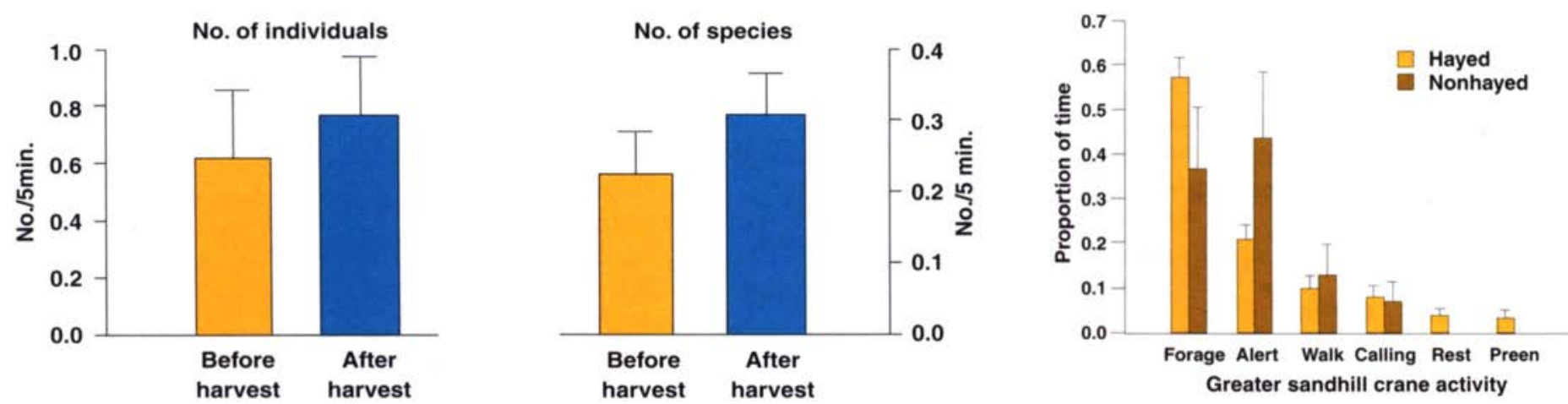

Fig. 4. Average number of individual birds ( \pm 1 S.E.) and average number of bird species observed two weeks before hay harvest and two weeks following harvest on hayed plots (F, G, H).

Fig. 5. Time-activity budgets of greater sandhill cranes on hayed and nonhayed plots (means \pm 1 S.E.). 
provide the mosaic of foraging habitat and vegetation cover required by many species of resident and migrant birds.

W.E. Epperson is Fish and Wildlife Scientific Aide, California Department of Fish and Game, ACWA, Bieber; J.M. Eadie is Raveling Waterfowl Professor and E.L. Fitzhugh is Extension Wildlife Specialist, Department of Wildlife, Fish and Conservation Biology, UC Davis; D.B. Marcum is Farm Advisor, Shasta/Lassen Counties; and R.E. Delmas is Farm Advisor, Modoc County.

The authors are grateful for equipment and access supplied by CDFG, for an internship provided by the Renewable Resources Extension Act, and financial assistance by the Pit Resource Conservation District. They thank Peter Gerig for allowing access to his private land in the marsh where one plot was established. They are especially grateful to Lee Ashford, ACWA manager, for technical support and input on the study.

\section{Further reading}

Baker BW, Cade BS, Mangus WL, McMille JL. 1995. Spatial analysis of sandhill crane nesting habitat. J Wildlife Management 59:752-8.

Dale BC, Martin PA, Taylor PS. 1997. Effects of hay management on grassland songbirds in Saskatchewan. Wildlife Society Bulletin 25:616-26.

Green RE, Tyler GA, Stowe TJ, Newton AV. 1997. A simulation model of the effect of mowing of agricultural grassland on the breeding success of the corncrake (Crex crex). J Zoology (London) 243:81-115.

Littlefield CD. 1995. Greater sandhill crane nesting and production in northeastern California, 1988. Western Birds 26:34-8.

Luttschwager KA, Higgins KF, Jenks JA. 1994. Effects of emergency haying on duck nesting in conservation reserve program fields, South Dakota. Wildlife Society Bulletin 22:403-8.

Mclvor DE, Conover MR. 1994. Habitat preference and diurnal use among greater sandhill cranes. Great Basin Naturalist 54:329-34.

Safina C. 1993. Population trends, habitat utilization, and outlook for the future of the sandhill crane in North America: A review and synthesis. Bird Populations 1:1-27.

Sietman BE, Fothergill WB, Finck EJ. 1994. Effects of haying and old-field succession on small mammals in tallgrass prairie. American Midland Naturalist 131:1-8.

Swengel AB. 1996. Effects of fire and hay management on abundance of prairie butterflies. Biological Conservation 76:73-85.

Swengel SR. 1996. Management responses of three species of declining sparrows in tallgrass prairie. Bird Conservation Intl 6:241-53.

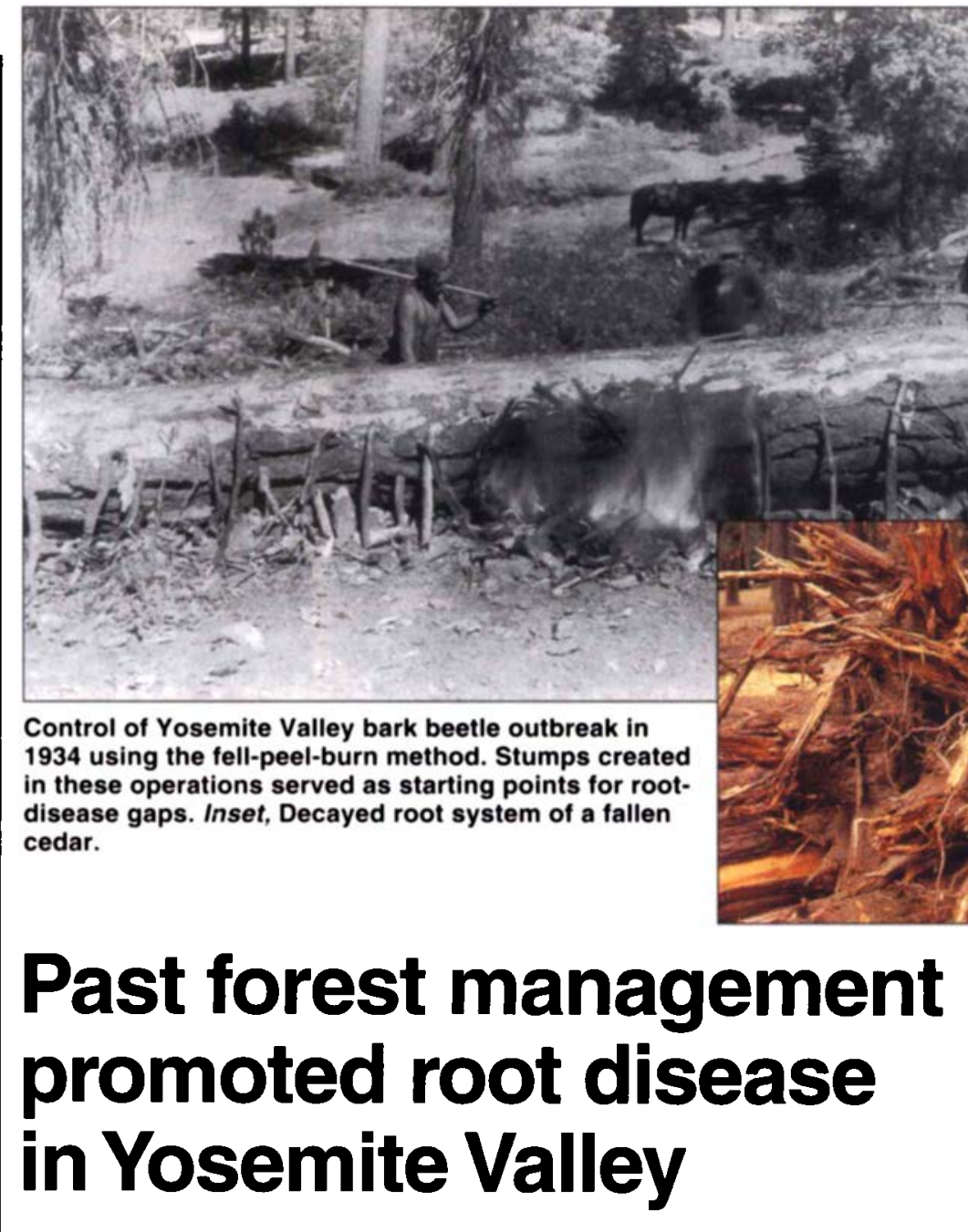

Garey W. Slaughter D David M. Rizzo

Root disease is one of the most important vegetation-management considerations in Yosemite Valley. Large trees with root decay have fallen in the valley causing human fatalities and property damage. Many of the problems associated with root disease in Yosemite Valley can be traced back to the area's history of vegetation management. Wildfire suppression and meadow draining were implemented after the arrival of Euroamericans in the mid-19th century. These practices created conditions that encouraged the development of a dense conifer forest within the valley. Tree removals for vista clearance, campground and lodging construction, and bark beet/e control projects created thousands of stumps.
Many of these stumps have been infected with spores of Heterobasidion annosum, a fungal pathogen that causes root decay in conifers. The fungus has since spread from initial infection sites into the surrounding forest, creating hundreds of enlarging tree mortality gaps. Park resource managers have established a program of hazardous-tree removal, but efforts to restore natural ecosystem processes must be continuously reconciled with public safety.

Yosemite National Park's resource managers are attempting to integrate ecosystem-based management techniques (such as prescribed burns) with the impact of 4 million visitors per year. We believe that the presence of 